\title{
Cytotoxicity of Plant Extract Origanum syriacum on Gametogenesis of Two Terrestrial Slugs, Using TEM
}

\author{
Abdel-Haleem AA* \\ Department of Biology, Faculty of Education, Ain Shams University, Cairo, Egypt
}

\begin{abstract}
The present study includes ultrastructural aspects of molluscicidal effects of wild botanic aqueous extract, namely Za'ater plant (Origanum syriacum) on the gametogenesis of two terrestrial slugs, giant grey slug Limax maximus and tree slug L. marginatus. L. marginatus was more susceptible to this plant than $L$. maximus $\left(\mathrm{LC}_{90}\right.$ are 445.1 and 460.2 for $L$. marginatus and $L$. maximus respectively). The present results revealed that Za'ater's extract had adverse effects on gametogenesis of the treated slugs, including marked inhibition of the various stages of gametogenesis, besides intracellular accumulation of the toxic agents of Za'ater-plant. Therefore, the treatment of the tested slugs with $\mathrm{LC}_{90}$ of Za'ater extract can be recommended for controlling such slugs in the field, instead of using chemical pesticides that continuously pollute the environment.
\end{abstract}

Keywords: Plant molluscicides; Origanum sp; Slugs; Limax spp; Ultrastructure (TEM)

\section{Introduction}

The giant grey slug Limax maximus [1] measures 10-20 cm in length and is generally light grey or grey-brown colored with darker spots and blotches. Concerning tree slug Limax marginatus [2], it can grow up to $7 \mathrm{~cm}$ in length, body colour is pale grey and is marked by two dark lines on both sides of the body and it is found mostly climbing trees.

Since few years, certain terrestrial slugs became serious gardenpests in Egypt infesting numerous agronomic, horticultural and ornamental plants.

Gamil [3] studied, in details, ultrastructure of spermatogenesisstages of the garden slug Limax flavus as well as Cuezzo [4] in mollusks of family Orthalicidae (Stylommatophora).

On the other hand, several wild plants have been screened for their molluscicidal activity against them. The plant molluscicides must have a high potency to slugs and low toxicity to non-tested living organisms. These plants must further be the source of cheap, effective and environmentally acceptable products [5]

In this concern, many plant extracts are products favoured as biocontrol agents against such slugs, from which the wild Za'ater plant (O. syriacum) was recommended [6-8].

Chemically, El-Desouky et al. [9] found, using spectroscopic and chromatographic methods, that the methanol crude extract of the aerial parts of O. syriacum has new flavone glycoside together with flavonoids luteolin, apigenin, luteolin-6-C-glucoside, luteolin-3'-methylether-6C-glucoside, luteolin-7, 4'-dimethyether-6-C-glucoside, apigenin-7methylether-6-C-glucoside, apigenin-7-O-glucoside, diosmetin-7-Oglucoside, acacetin-7-O-glucoside and acacetin-7-O-rutinoside.

The present study aimed to examine the effect of the plant $O$. syriacum on the slugs L. maximus and L. marginatus, manifested by the ultrastructural changes in their gametogenetic stages.

\section{Material and Methods}

\section{Samples of the slugs}

The present species of slugs, L. maximus and L. marginatus were manually collected from the garden of Faculty of Education, Ain Shams
University, Roxy, Cairo, through July 2006. They were reared under laboratory conditions and daily fed on lettuce leaves whereas the dried plant O. syriacum had obtained from a folk market at Cairo city.

\section{Preparation of plant extract}

Water extract of $O$. syriacum plant was prepared according to the method of Wada and Munakata [10], cited by Abdel-Haleem [8]. The preparation of the present plant extract included over-drying the tested plant in an electric oven, adjusted at $50^{\circ} \mathrm{C}$ for three days. Then, ethanol (70\%) and plant-leaves had homogenated, filtered and evaporated in adjusted electric oven at $70^{\circ} \mathrm{C}$ to obtain gum-shaped substance. The obtained residue had dissolved in distilled water, at ratio 1:5 by volume. Finally, the obtained plant extract had used to prepare all aqueous concentrations to determine $\mathrm{LC}_{50}$ and $\mathrm{LC}_{90}$ of the plant extract.

The slugs of each species were divided into two groups, untreated and treated and the method of El-Wakil and Radwan [11] was used to evaluate the effectiveness of the plant extract against the tested slugs.

\section{Determination of $\mathrm{LC}_{50}$ and $\mathrm{LC}_{90}$ of Za'ater plant}

To determine $\mathrm{LC}_{50}$ and $\mathrm{LC}_{90}$ of Za'ater-plant, 4 concentrations of the plant $(150,300,450$ and $600 \mathrm{mg})$ were prepared and applied against the tested slugs for 48 hours (using 100 slugs/concentration per each species). Regression mortality lines and corresponding mortalities were established on log dose-mortality sheet. $\mathrm{LC}_{50}$ and $\mathrm{LC}_{90}$ values were calculated according to the method of Finney [12].

\section{Ultrastructural technique}

This technique included: anesthetizing the slugs with $30 \%$ ethyl

*Corresponding author: Abdel-Haleem AA, Department of Biology, Faculty of Education, Ain Shams University, Cairo, Egypt, Tel: 202 26831474; E-mail: abddelsalam1958@windowslive.com

Received January 27, 2014; Accepted February 25, 2014; Published February 27, 2014

Citation: Abdel-Haleem AA (2014) Cytotoxicity of Plant Extract Origanum syriacum on Gametogenesis of Two Terrestrial Slugs, Using TEM. J Cytol Histol 5: 224 doi:10.4172/2157-7099.1000224

Copyright: (C) 2014 Abdel-Haleem AA. This is an open-access article distributed under the terms of the Creative Commons Attribution License, which permits unrestricted use, distribution, and reproduction in any medium, provided the original author and source are credited. 
Citation: Abdel-Haleem AA (2014) Cytotoxicity of Plant Extract Origanum syriacum on Gametogenesis of Two Terrestrial Slugs, Using TEM. J Cytol Histol 5: 224. doi:10.4172/2157-7099.1000224

alcohol, dissection to obtain the hermaphrodite gland, cutting the gland of each slug into small pieces, fixing with $2.5 \%$ paraformaldehyde- $3 \%$ glutaraldehyde ( $\mathrm{pH}$ 6.7) at room temperature and post-fixed with (1\%) phosphate buffered $\mathrm{OsO}_{4}$, rinsing the specimens in $0.2 \mathrm{M}$ phosphate buffer ( $\mathrm{pH}$ 7.3), dehydration in ethyl alcohol and embedding in Epon 812 mixture. Then, semi-thin sections were obtained with LKB-V ultramicrotome, stained with uranyl acetate and lead citrate and finally examined under transmission electron microscope (TEM) (JEM $100 \mathrm{CX}-\mathrm{II}, 80 \mathrm{kV}$ ).

\section{Results}

\section{Susceptibility of slugs to the plant extract}

(Table 1) and (Figures 1 and 2) show the susceptibility of the slugs Limax maximus and L. marginatus to Za'ater-extract, where L. marginatus was more susceptible to this plant than $L$. maximus, i.e. $L$. maximus recorded higher mean mortality percentage than $L$. marginatus, where $\mathrm{LC}_{50}$-values of Za'ater were 217.4 and 241.9 whereas

\begin{tabular}{|l|c|c|}
\hline \multirow{2}{*}{ Conc. $(\mathbf{p p m})$} & \multicolumn{2}{|c|}{ Dead slugs (Mean\% $\mathbf{\text { SD) }}$} \\
\hline $\mathbf{1 5 0}$ & L. maximus & L. marginatus \\
\hline $\mathbf{3 0 0}$ & $12 \pm 0.75$ & $16 \pm 1.41$ \\
\hline $\mathbf{4 5 0}$ & $62 \pm 0.47$ & $69 \pm 1.25$ \\
\hline $\mathbf{6 0 0}$ & $88 \pm 1.33$ & $91 \pm 0.47$ \\
\hline Control & $96 \pm 0.25$ & $98 \pm 2.05$ \\
\hline
\end{tabular}

Table 1: Susceptibility of $L$. maximus and $L$. marginatus slugs to $O$. syriacum extract.

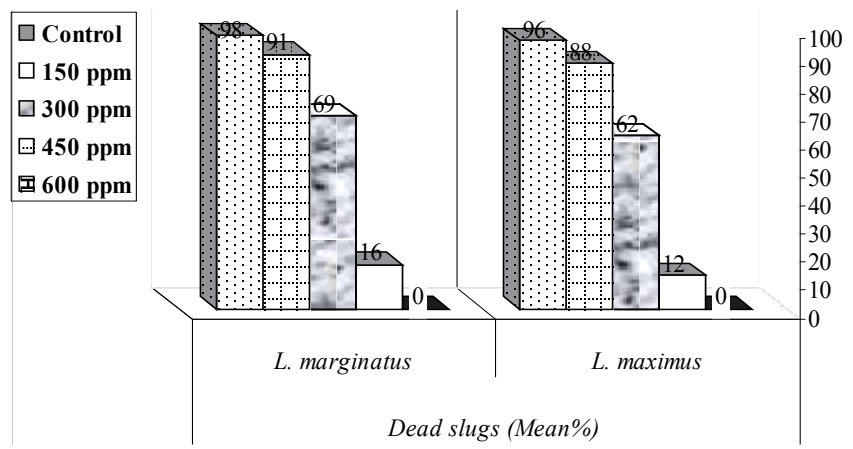

Figure 1: Susceptibility of $L$. maximus and $L$. marginatus slugs to $O$. syriacum extract.

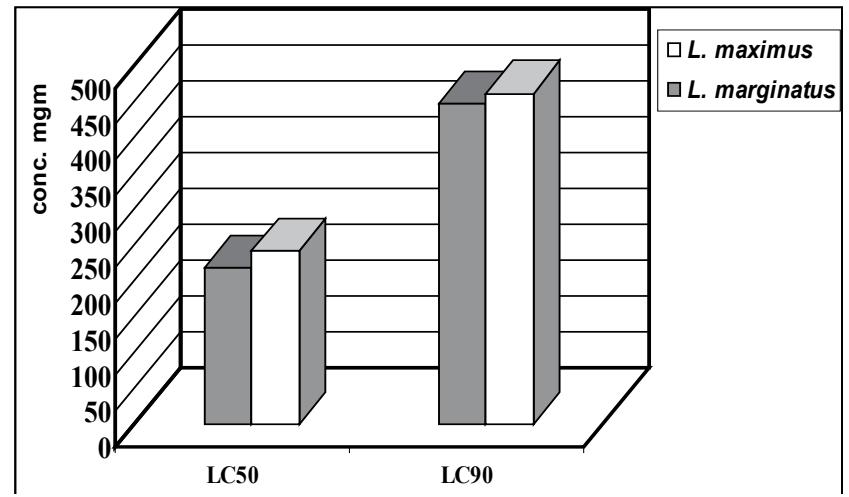

Figure 2: Diagramatic representation of $\mathrm{LC}_{50}$ and $\mathrm{LC}_{90}$ of the extract of $\mathrm{O}$. syriacum plant against the slugs, $L$. maximus and $L$. marginatus.

\begin{tabular}{|l|c|c|}
\hline Concentrations & L. maximus & L. marginatus \\
\hline LC $_{50}$ & 241.9 & 217.4 \\
\hline LC $_{90}$ & 460.2 & 445.1 \\
\hline
\end{tabular}

Table 2: $L C_{50}$ and $L C_{90}$ of the slugs, L. maximus and L. marginatus.

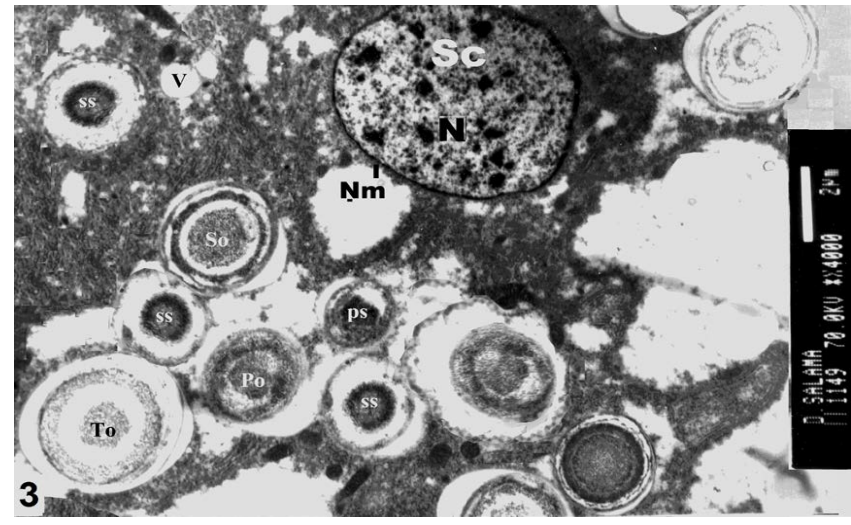

Figure 3: Transmission Electron Micrograph (TEM) of non-treated (control) hermaphrodite gland of $L$. marginatus slug showing most of stages of gametogenesis as well as Sertoli cell. (Po=primary oocyte, So=Secondary oocyte, $\mathrm{Ps}=$ Primary spermatocyte, ss=Secondary spermatocyte, $\mathrm{N}=$ =nucleus, $\mathrm{Nm}=$ nuclear envelope, $\mathrm{Sc}=$ Sertoli cell, v=vacuole $(X=4000)$.

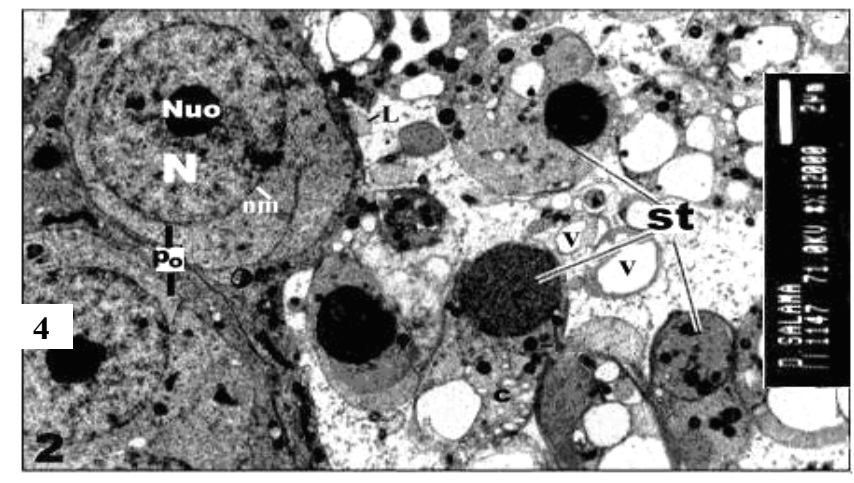

Figure 4: Magnified part of the hermaphrodite gland of non-treated (control) of the slug L. maximus to show primary oocytes and stages of developing spermatids. (Po=primary oocytes, $\mathrm{N}=$ nucleus, $\mathrm{nm}=$ nuclear envelope, Nuo=nucleolus, $v=$ vacuole, $\mathrm{L}=\mathrm{Ly}$ sosome, $\mathrm{St}=$ stages of developing spermatids, $X=12000$ ).

$\mathrm{LC}_{90}$ were 445.1 and 460.2 for L. marginatus and L. maximus respectively (Table 2).

Ultrastructural effects of $O$. syriacum on the gametogenesis of the tested slugs

The present results of untreated $L$. maximus-slug, using Transmission Electron Microscope (TEM), are nearly similar to those of L. marginatus, displaying some stages of gametogenesis (Figures 3 and 4).

High power-TEM of the hermaphrodite gland of L. marginatus shows numerous primary oocytes, with some cellular organelles, and stages of developing spermatids to form sperms. The primary oocytes have relatively large nucleus and one nucleolus. The developing spermatids including pro-acrosomal granule, that has obvious aggregated rod-shaped mitochondria, as showing in (Figure 4) that will form acrosomes. 


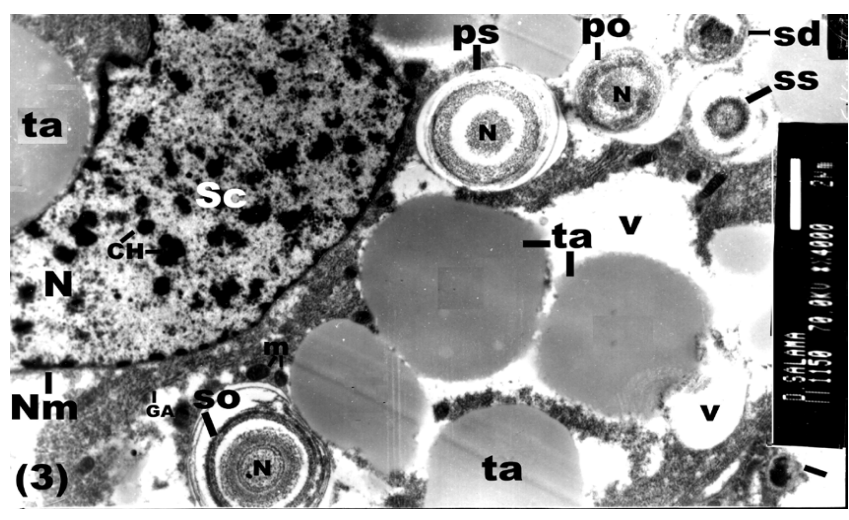

Figure 5: TEM of the hermaphrodite gland of treated $L$. maximus with $\mathrm{LC}_{90}$ of Za'ater-extract showing scattered vacuoles (v), depression in the gametogenesis stages as a result of intracellular aggregation of toxic agent (ta) of the tested plant. ( $\mathrm{N}=$ nucleus, $\mathrm{SC}=$ Sertoli cell, $\mathrm{CH}=$ chromatin, $\mathrm{Ps}=$ primary spermatocyte, ss=secondary spermatocyte, $\mathrm{Po}=$ primary oocyte, So=secondary oocyte, sd=spermatid, ta=toxic agent, $X=4000$ ).

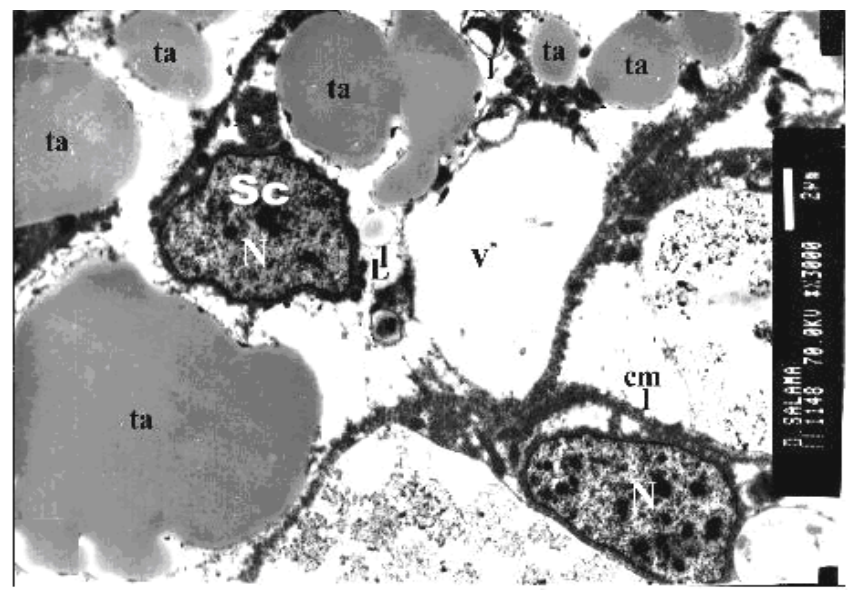

Figure 6: TEM of the hermaphrodite gland of treated $L$. marginatus with $\mathrm{LC}_{90}$ of Za'ater-extract showing scattered vacuoles $(\mathrm{v})$, depression in the gametogenesis stages as a result of intracellular aggregation of toxic agent (ta) of the tested plant. ( $\mathrm{N}=$ nucleus, $\mathrm{Sc}=$ Sertoli cell, $\mathrm{cm}=$ cell membrane, $\mathrm{L}=$ Lysosome, $\mathrm{X}=3000$ ).

Toxicologically, the present results revealed that $\mathrm{LC}_{50}$ of Za'aterextract was not effective against the stages of gametogenesis in both species of slugs, whereas $\mathrm{LC}_{90}$ affected the tested slugs and gametogenesisstages in $L$. marginatus were more affected by this extract than in $L$. maximus. The fine cellular changes were shown by disappearance of most of the organelles, leaving apparent large vacuoles, shrinkage of Sertoli cells in L. marginatus, besides intracellular aggregations of large blocks of toxic agents of Za'ater-extract in the two species of slugs (Figures 5 and 6).

\section{Discussion}

Relevant works have been focused on potency of plant molluscicides regarding their isolation, purification and extraction, besides determination of biological effects on the slugs and snails (Fonghua et al. 2000) [5]

The present work indicated that Zaater-extract was effective against the slugs Limax maximus and L. marginatus and the latter was more affected. In this respect, El-kassas [7] studied the molluscicidal potency of six Egyptian wild plants, including O. syriacum, against the freshwater snails Bulinus truncatus and Biomphalaria alexandrina. She found that $O$. syriacum was the most toxic to the two snail-species.

Cytologically, Hill and Bowen [13] showed that the development of the oocyte of the slug Agriolimax reticulatus into mature ovum was divided into three stages. The oocyte-cytoplasm of stage I contains most of the organelles and the nucleus contains two nucleoli. The oocyte of stage II has lipid and glycogen droplets and yolk platelets, whereas those of stage III were enlarged and their plasma membrane has microvilli and pinocytotic tubules and the cytoplasmic organelles were fuse with the growing yolk platelets while their nuclei contains only one nucleolus Sakr et al. [6] studied the fine structure of spermatogenesis stages besides Sertoli cells of the slug Agriolimax reticulates. They showed the typical architecture of spermatogenesis and the different stages of developing spermatids. They revealed that the acrosome is initiated from pro-acrosomal granule that probably derived from Golgi apparatus, axial filament formed from centrioles, the mitochondria formed mitochondrial sheath around the axial filament of the mid-piece. Furthermore, they found that the shape of Sertoli cells was changed during spermatogenesis. The present ultrastructural results reinforced the above findings. In this respect, Eckelbarger and Eyster [14] reported the spermatid development in the mollusk Spurilla neapolitana and found that it is distinguished into stages namely: precup, cup, postcup, and elongated forms and that the spermatozoa develop by numerous desmosomes in the proximal half of sac-like acini within ovotestis lobes. The present ultrastructural results agree with such finding.

Parivar [15] recognized active- and atrophyc-Sertoli cells of Arion ater slug. The cytoplasm of the active one revealed many organelles, whereas the cytoplasm of atrophyc cells was nearly devoid of organelles. The present results of untreated and treated Sertoli cells of the tested slugs support the latter study.

On the other hand, Chang and Jeong [16] had cytologically studied the seasonal changes of the hermaprodite duct epithelium in spring and summer of the slug Incilaria fruhstorferi and suggested that this epithelium exhibits seasonal variation in relation to their reproductive cycle.

Cuezzo [17] studied the fine structure of the sperm of the snail Epiphragmophora tucumanensis and reported the absence of their annulus and glycogen piece.

Bojat et al. $[18,19]$ cytologically investigated spermathecal muscles in the land snails, Arianta arbustorum and Bradybaena fruticum. They found that the musculature of $A$. arbustorum surrounding 2-9 tubules and the unitubular spermatheca of $B$. fruticum exert cryptic female choice. In this respect, Rogers and Reeder [20] studied the ultrastructure of the spermatheca of Biomphalaria glabrata to compare its structure to similar organs in other species.

Recently, Pal [21] examined the fine structure of the reproductive gland in the pulmonates, Siphonaria capensis and S. serrata. In both species, he found that the glandular complex; included secretory cells, ciliated supporting cells, albumen gland and mucous gland; is the most primitive organization of the reproductive glands in pulmonates.

Chemically, Kamel et al. [22] studied aerial parts of Origanum syriacum-plant and extracted three monoterpene glucosides; thymoquinol 2,5-O- $\beta$-diglucopyranoside, carvacrol 2-O- $\beta$ glucopyranosyl-( $(1 \rightarrow 2)$ - $\beta$-glucopyranoside and $\mathrm{p}$-menth-1-ene-3,4-diol 4 -O- $\beta$-glucopyranoside, beside two known compounds; thymoquinol 2 -O- $\beta$-glucopyranoside and thymoquinol 5 -O- $\beta$-glucopyranoside. 
Citation: Abdel-Haleem AA (2014) Cytotoxicity of Plant Extract Origanum syriacum on Gametogenesis of Two Terrestrial Slugs, Using TEM. J Cytol Histol 5: 224. doi:10.4172/2157-7099.1000224

In this concern, El-Desouky et al. [9] found that the methanol crude extract of the aerial parts of Origanum syriacum has a new flavone glycoside (acacetin-7-O-[2"-O- $\alpha$-L-rhamnopyranosyl-6"-O$\beta$-D-glucopyranosyl]- $\beta$-D-glucopyranoside) together with flavonoids luteolin, apigenin, luteolin-6-C-glucoside, luteolin-3'-methylether-6C-glucoside, luteolin-7, 4'-dimethyether-6-C-glucoside, apigenin-7methylether-6-C-glucoside, apigenin-7-O-glucoside, diosmetin-7-Oglucoside, acacetin-7-O-glucoside and acacetin-7-O-rutinoside.

The present result recommends the application of $\mathrm{LC}_{90}(460.2 \mathrm{mg})$ of $O$. syriacum-extract for the biocontrol of the present slugs in their natural habitats, instead of using chemical pesticides that continuously pollute the environment. In this concern, El-Wakil [23] isolated two flavonoid glycosides from aerial parts of the plant Fagonia arabica and identified as kaempferol-7-O-rhamnoside and acacetin-7-Orhamnoside. Then, four triterpenoidal glycosides were isolated from the butanolic layer (on the basis of the spectral and chemical data), from which two compounds were found to possess strong molluscicidal activity against Biomphalaria alexandrina snails in Egypt $\left(\mathrm{LC}_{90}=13.33\right)$, as in figure; 3-O-d-glucopyranosyl- $\alpha$-l-arabinopyranoside oleanolic acid and 3-O-d-glucopyranosyl-d-glucopyranosyl- $\alpha$-l-arabinosyl oleanolic acid.

\section{References}

1. Linnaeus C (1758) Systema naturae per regna tria naturae, secundum classes, ordines, genera, species, cum characteribus, differentiis, synonymis, locis. Tomus I. Editio decima, reformata. 1-4, 1-824. Holmiae. (Salvius).

2. Müller OF (1774) Vermivm terrestrium et fluviatilium, seu animalium infusoriorum, helminthicorum, et testaceorum, non marinorum, succincta historia. Volumen alterum. 1-10. (Heineck \& Faber).

3. Gamil IS (2013) Spermatogenesis and Sperm ultrastructure in the Land Slug Limax flavus (Gastropoda, Pulmonata) from Egypt. Advances in Biological Research 7: 253-265.

4. Cuezzo MG (2011) Ultrastructure of spermatozoa in Orthalicidae (Mollusca, Gastropoda, Stylommatophora) and its systematic implications. Zoomorphology 130: 147-166.

5. Fonghua WEI, Xingjian XU, Yuhai DAI, Jianbin LIU (2000) Study of plant molluscicide from Solarium xanthocarpum extraction. Hubei Institute of Schistosomiasis Control, Wujian, China.

6. Sakr SA, Saleh AT, Osman GY, Lamfon HA (1998) Ultrastructural study on spermatogenesis in the slug Agriolimax reticulatus. J Egypt Ger Soc Zool 27: 1-11.

7. El-Kassas NBE (2001) Integrated effect of some mosquito larvicides and molluscicides as biological control agents against mosquitos and snails. Ph.D Thesis, Faculty of Science, Ain Shams University, Cairo, Egypt.

8. Abdel-Haleem AA (2003) Molluscicidal potency and histopathological effects of three Egyptian wild plant extracts against the freshwater snails Lanistes bolteni and Lymnaea natalensis. J Egypt Ger Soc Zool 42D: 157-169.

9. El-Desouky SK, Ibrahim LF, Kawashty SA, El-Ansari MA, Kim Yeongsuk, et al. (2009) Phytochemical constituents and biological activities of Origanum syriacum. Z Naturforsch 64: 447-451.
10.Wada K, Munakata K (1968) Naturally occurring insect chemicals: Isoboldine a feeding inhibitor and coculodidine an insecticide in the leaves of Cocculus trilobus. T Agric Food Chem 16: 471: 74.

11. el-Wakil HB, Radwan MA (1991) Biochemical studies on the terrestrial snail, Eubania vermiculata (Müller) treated with some pesticides. J Environ Sci Health B 26: 479-489.

12.Finney DJ (1952) Probit analysis. Cambridge University Press, 3rd, London, UK.

13. Hill RS, Bowen ID (1976) Studies on the ovotestis of the slug Agriolimax reticulatus (Müller). Cell Tissue Res 173: 465-482.

14.Eckelbarger KJ, Eyster LS (2005) An ultrastructural study of spermatogenesis in the nudibranch mollusk Spurilla neapolitana. J of Morphol 170: 283-299.

15.Parivar K (1980) Differentiation of Sertoli cells and post-reproductive epithelial cells in the hermaphrodite gland of Arion ater (L.) (Mollusca, Pulmonata). J Mollus Stud 46: 139-147.

16.Chang NS, Jeong KH (1996) Ultrastructural changes of the hermaphrodite duct epithelium by season in the Korean Incilaria fruhstorferi. Korean J Zool 392: 139-146.

17.Cuezzo MG (1995) Ultrastructure of the mature spermatozoa of the land snail Epiphragmophora tucumanensis (Doering, 1874) (Gastropoda: Helicoidea). J Mollus Stud 61: 1-7.

18.Bojat NC, Durrenberger M, Haase M (2001) The spermatheca in the land snail, Arianta arbustorum (Pulmonata: Stylommatophora): Muscle system and potential role in sexual selection. Invertebrate Biology 120: 217-226.

19.Bojat NC, Sauder U, Haase M (2004) Functional anatomy of the sperm storage organs in Pulmonata: the simple spermatheca of Bradybaena fruticum (Gastropoda, Stylommatophora). Zoomorphology 121: 243255.

20.Rogers SH, Reeder RL (1987) Structure and function of the spermatheca in a snail host of schistosomiasis, Biomphalaria glabrata. J Morphol 191: 295-308.

21.Pal $P$ (2007) Fine structure of reproductive glands in two primitive marine pulmonates (Basommatophora: Siphonariidae). Acta Zoologica 88: 145-152.

22. Kamel MS, Assaf MH, Hasanean HA, Ohtani K, Kasai R, et al. (2001) Monoterpene glucosides from Origanum syriacum. Phytochemistry 58: 1149-1152.

23. El-Wakil EA (2007) Phytochemical and molluscicidal investigations of Fagonia arabica. Z Naturforsch C 62: 661-667. 